\title{
MOTIVASI PENGAWAS AGAMA HINDU SEKOLAH DASAR DI KECAMATAN UBUD
}

\author{
Oleh \\ Ni Wayan Arini dan Putu Santi Oktarina \\ wayanarini1967@gmail.com; putusantioktarina@gmail.com \\ Institut Hindu Dharma Negeri Denpasar
}

\begin{abstract}
ABSTRAK
Peningkatan profesionalistas guru dalam bidang pendidikan terutama pendidikan agama dan pembangunan tidak lepas dari peranan motivasi pengawas terhadap produktivitas kerja warga sekolah. Pemimpin sekolah pada suatu organisasi sekolah dalam menyediakan pelayanan yang mampu bersaing dalam era globalisasi seperti saat ini. Kualitas pemimpin sekolah yang baik adalah sebagai dasar utama dalam menyiapkan sumber daya manusia yang mampu bersaing dalam dunia global, tentunya diperlukan pengelolaan secara profesional dalan bidang pendidikan terutama di tingkat pendidikan dasar dan menengah. Pengawas sekolah sebagai tenaga kependidikan mempunyai peran yang sangat strategis dalam meningkatkan kualitas kinerja sekolah melalui pembinaan, pengawasan di bidang akademik dan manajerial. Beratnya tugas seorang pengawas sekolah dalam melaksanakan tugas pokok, fungsi dan tanggung jawab serta wewenangnya itu hanya dapat dipikul oleh seorang pengawas yang memiliki kompetensi yang baik. Motivasi kerja pengawas Agama Hindu di Kecamatan Ubud sangat baik, karena mampu memberikan rasa nyaman dalam melaksanakan tugas-tugas dalam mengelola pembelajaran, mampu membina rasa social, persahabatan, rasa kekeluargaan terhadap guru-guru Agama Hindu, menghargai dan menghormati kerja keras guru dalam melaksanakan tugas-tugasnya, dan memberikan dorongan kepada guru-guru dalam mengembangkan setip potensi atau kempuan terhadap perkembangan karier guru.
\end{abstract}

\section{Kata Kunci: Motivasi Kerja Pengawas Agama Hindu}

\section{PENDAHULUAN}

Standar pendidik dan tenaga kependidikan yang diatur dalam Peraturan Menteri Pendidikan Nasional Nomor 16 Tahun 2007 serta Peraturan Pemerintah Nomor 74 Tahun 2008 tentang Guru, mengamanatkan bahwa guru wajib memiliki kompetensi pedagogik, kompetensi kepribadian, kompetensi sosial, dan kompetensi profesional. Kompetensi padagogik merupakan kemampuan dalam mengelola peserta didik, kompetensi kepribadian dan kompetensi sosial merupakan kemampuan pendidik sebagai bagian dari masyarakat, serta kompetensi profesional merupakan kemampuan guru dalam menguasai bidang ilmu pengetahuan, teknologi, dan/atau seni dan budaya yang diampu sekurang-kurangnya meliputi penguasaan materi pelajaran secara luas dan mendalam sesuai dengan standar isi program satuan pendidikan, mata pelajaran, dan/atau 
kelompok mata pelajaran yang akan diampu.

Peningkatan profesionalistas guru dalam bidang pendidikan terutama pendidikan agama dan pembangunan di Provinsi Bali, semua itu tidak lepas adanya peranan motivasi pengawas terhadap produktivitas kerja warga sekolah. Pemimpin sekolah pada suatu organisasi sekolah dalam menyediakan pelayanan yang mampu bersaing dalam era globalisasi seperti saat ini. Kualitas pemimpin sekolah yang baik adalah sebagai dasar utama dalam menyiapkan sumber daya manusia yang mampu bersaing dalam dunia global, tentunya diperlukan pengelolaan secara profesional dalan bidang pendidikan terutama di tingkat pendidikan dasar dan menengah.

Peraturan Menteri Pendidikan Nasional RI Nomor 12 Tahun 2007 tentang Standar Pengawas Sekolah/Madrasah merupakan acuan dasar bagi pengawas yang memuat kualifikasi dan kompetensi pengawas sekolah di setiap jenjang pendidikan. Peraturan Menteri Pendidikan Nasional Nomor 12 Tahun 2007 memuat pula apa yang menjadi syarat minimum pendidikan seorang pengawas, memiliki sertifikat pendidik, pangkat dan golongan, usia, uji kompetensi atau pendidikan dan pelatihan fungsional pengawas dan lulus seleksi serta kompetensi yang terdiri dari kompetensi kepribadian, kompetensi supervisi manajerial, supervisi akademik, kompetensi evaluasi pendidikan, kompetensi penelitian dan pengembangan, dan kompetensi sosial dengan rinci.
http://ejournal.ihdn.ac.id/index.php/AW

\begin{tabular}{lrr}
\multicolumn{2}{c}{ Implementasi } & kompetensi \\
pengawas & sekolah & di r satuan \\
pendidikan & adalah & melakukan
\end{tabular}
supervisi manajerial yakni menilai dan membina kepala sekolah dan tenaga kependidikan lain yang ada di sekolah dalam mempertinggi kualitas pengelolaan administrasi dan supervisi akademik pengawas, yang berhubungan langsung dengan kinerja guru di kelas. Supervisi akademik adalah kegiatan menilai dan membina guru dalam rangka meningkatkan kualitas proses pembelajaran agar diperoleh hasil belajar peserta didik yang lebih optimal (Nana Sujana 2010:1), sedangkan dalam Buku Kerja Pengawas Sekolah yang diterbitkan oleh Direktorat Tenaga Kependidikan, Direktorat Jenderal Peningkatan Mutu Pendidik dan Tenaga Kependidikan, Kementerian Pendidikan Nasional tahun 2010 menjelaskan bahwa supervisi akademik atau pengawasan akademik adalah fungsi pengawas yang berkenaan dengan aspek pelaksanaan tugas pembinaan, pemantauan, penilaian dan pelatihan profesional dalam melaksanakan tugas pokoknya sesuai dengan Peraturan Pemerintah Nomor 74 Tahun 2008 pasal 52 ayat 1 yaitu beban kerja guru mencakup kegiatan pokok: merencanakan pembelajaran, melaksanakan pembelajaran, melaksanakan pembelajaran, menilai hasil pembelajaran, membimbing dan melatih peserta didik dan melaksanakan tugas tambahan yang melekat pada pelaksanaan kegiatan pokok sesuai dengan beban kerja guru.

Ubud merupakan salah satu daerah tujuan wisata baik domestik maupun mancanegara dengan 
kehidupan masyarakat yang multikultural. Dalam hal ini tentunya berpengaruh terhadap perkembangan kehidupan peserta didik, sehingga guru dan pengawas sekolah sangat memiliki peranan yang sangat penting terhadap perilaku anak didik. Fenomena inilah yang membuat peneliti tertarik meneliti tentang Motivasi Pengawas Agama Hindu di Sekolah Dasar seKecamatan Ubud.

\section{PEMBAHASAN}

\section{Pengertian Motivasi}

Motivasi pada dasarnya merupakan kondisi mental yang mendorong pemimpin melakukan suatu tindakan atau aktivitas (actions or activities) dalam konteks ini adalah pengawas agama dan memberikan kekuatan yang mengarah kepada perencanaan pemenuhan keinginan, memberikan kepuasan, atupun mengurangi ketidakseimbangan (Kompri, 2017: 82). Menurut Sudarwan Danin 2010 (dalam Kompri, 2017) motivasi merupakan dorongan pemimpin, termasuk kepala sekolah, untuk bertindak dengan cara tertentu. Dengan kata lain motivasiadalah energi yang mendorong orang (pemimpin) untuk melakukan aktivitas, baik untuk tujuan pemenuhan kebutuhan fisiologi, rasa aman, pengakuan sosial , penghargaan maupun realisasi diri.Jadi motivasi bisa muncul karena faktor luar maupun faktor dalam. Menurut Uno ( 2007) motivasi dapat diartikan sebagai dorongan internal dan ekternal dalam diri seseorang yang diindikasikan dengan adanya hasrat dan minat.

\section{Menurut George $R$. dan}

Leslie W. (dalam bukunya Matutina. dkk , 1993) mengatakan bahwa motivasi adalah "......getting a person to exert a high degree of effort ..." yang artinya motivasi membuat seseorang bekerja lebih berprestasi. Sedang Ravianto (1986) dalam bukunya ada beberapa faktor yang dapat mempengaruhi motivasi kinerja, yaitu atasan, rekan, sarana fisik, kebijaksanaan dan peraturan, imbalan jasa uang, jenis pekerjaan.

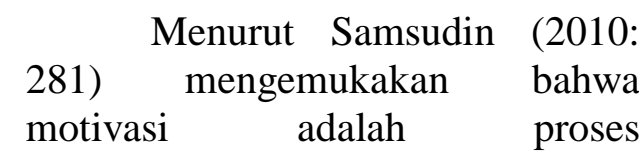
mempengaruhi atau mendorong dari luar terhadap seseorang atau kelompok kerja agar mereka mau melaksanakan sesuatu yang telah ditetapkan. Sedangkan menurut Liang Gie dalam Samsudin menyatakan bahwa motivasi adalah pekerjaan yang dilakukan oleh manajer dalam memberikan inspirasi, semangat dan dorongan kepada orang lain, dalam hal ini karyawannya, untuk mengambil tindakan-tindakan tertentu.

Menurut Sulistiyani (2003:58), motivasi adalah proses pemberian dorongan kepada anak buah agar anak buah dapat bekerja sejalan dengan batasan yang diberikan guna mencapai tujuan organisasi secara optimal. Sedangkan menurut Richard M. Stears dalam Sedarmayanti (2009: 233), motivasi adalah kekuatan kecenderungan seorang individu melibatkan diri dalam kegiatan yang berarahkan sasaran dalam pekerjaan. Ini bukan perasaan senang yang relatif terhadap hasil berbagai pekerjaan sebagaimana halnya kepuasan, tetapi lebih merupakan perasaan sedia/rela bekerja untuk mencapai tujuan pekerjaan.

Selain itu menurut Siagian (2009: 102), menyatakan bahwa 
motivasi merupakan daya dorong bagi seseorang untuk memberikan kontribusi yang sebesar mungkin demi keberhasilan organisasi mencapai tujuannya. Berbeda lagi dengan pendapat Edwin B. Flippo dalam Hasibuan (2010: 143), motivasi adalah suatu keahlian, dalam mengarahkan pegawai dan organisasi agar mau bekerja secara berhasil, sehingga keinginan para pegawai dan tujuan organisasi sekaligus tercapai.

Berdasarkan uraian pendapat dari para ahli di atas, dapat disimpulkan bahwa motivasi adalah dorongan atau perangsang yang membuat seseorang melakukan pekerjaan yang diinginkannya dengan rela tanpa merasa terpaksa sehingga pekerjaan yang dilakukan dapat berjalan dengan baik atau menghasilkan sesuatu yang memuaskan.

\section{Faktor-faktor Motivasi}

Menurut Sunyoto (2013: 13-

17) faktor-faktor motivasi ada tujuh yaitu:

a. Promosi

Promosi adalah kemajuan seorang karyawan pada suatu tugas yang lebih baik, baik dipandang dari sudut tanggung jawab yang lebih berat, martabat atau status yang lebih tinggi, kecakapan yang lebih baik, dan terutama tambahan pembayaran upah atau gaji.

b. Prestasi Kerja

$$
\text { Pangkal }
$$

tolak

pengembangan

karier

seseorang adalah prestasi kerjanya melakukan tugastugas yang dipercayakan kepadanya sekarang. Tanpa prestasi kerja yang memuaskan, sulit bagi seorang karyawan untuk diusulkan oleh atasannya agar dipertimbangkan untuk dipromosikan ke jabatan atau pekerjaan yang lebih tinggi di masa depan.

c. Pekerjaan itu sendiri

Tanggung jawab dalam mengembangkan karier terletak pada masing-masing pekerja. Semua pihak seperti pimpinan, atasan langsung, kenalan dan para spesialis di bagian kepegawaian, hanya berperan memberikan bantuan, semua terserah pada karyawan yang bersangkutan, apakah akan memanfaatkan berbagai kesempatan mengembankan diri atau tidak.

d. Penghargaan

Pemberian motivasi dengan melalui kebutuhan penghargaan, seperti penghargaan atas prestasinya, pengakuan atas keahlian dan sebagainya. Hal yang sangat diperlukan untuk memacu gairah kerja bagi pada karyawan. Penghargaan di sini dapat merupakan tuntutan faktor manusiawi atas kebutuhan dan keinginan untuk menyelesaikan suatu tantangan yang harus dihadapi.

e. Tanggung Jawab

Pertanggungjawaban atas tugas yang diberikan perusahaan kepada para karyawan merupakan timbal balik atas kompensasi yang diterimanya. Pihak perusahaan memberikan apa yang diharapkan oleh para karyawan, namun di sisi lain para karyawan pun harus memberikan kontribusi penyelesaian pekerjaan dengan baik pula dan penuh dengan 
tanggung jawab sesuai dengan bidangnya masing-masing.

f. Pengakuan

Pengakuan atas kemampuan dan keahlian bagi karyawan dalam suatu pekerjaan merupakan suatu kewajiban oleh perusahaan. Karena pengakuan tersebut merupakan salah satu kompensasi yang harus diberikan oleh perusahaan kepada karyawan yang memang mempunyai suatu keahlian tertentu dan dapat melaksanakan pekerjaan dengan baik pula. Hal ini akan dapat mendorong para karyawan yang mempunyai kelebihan di bidangnya untuk berprestasi lebih baik lagi.

g. Keberhasilan dalam Bekerja

Keberhasilan dalam bekerja dapat memotivasi para karyawan untuk lebih bersemangat dalam melaksanakan tugas-tugas yang diberikan oleh perusahaan. Dengan keberhasilan tersebut setidaknya dapat memberikan rasa bangga dalam perasaan karyawan bahwa mereka telah mampu mempertanggungjawabkan apa yang menjadi tugas mereka.

\section{Langkah-langkah Motivasi}

Dalam memotivasi bawahan, ada beberapa petunjuk atau langkahlangkah yang perlu diperhatikan oleh setiap pemimpin. Adapun langkahlangkah tersebut menurut Sunyoto (2013: 17), adalah sebagai berikut:

1. Pemimpin harus tahu apa yang dilakukan bawahan.

2. Pemimpin harus berorientasi kepada kerangka acuan orang.
3. Tiap orang berbeda-beda di dalam memuaskan kebutuhan

4. Setiap pemimpin harus memberikan contoh yang baik bagi para karyawan

5. Pemimpin mampu mempergunakan keahlian dalam berbagai bentuk

6. Pemimpin harus berbuat dan berlaku realistis

\subsection{Tujuan Motivasi}

Adapun tujuan motivasi menurut Sunyoto (2013: 17-18) adalah sebagai berikut:

1. Mendorong gairah dan semangat kerja karyawan

2. Meningkatkan moral dan kepuasan kerja karyawan

3. Meningkatkan produktivitas kerja karyawan

4. Mempertahankan loyalitas dan kestabilan karyawan

5. Meningkatkan kedisiplinan dan menurunkan tingkat absensi karyawan

6. Mengefektifkan pengadaan karyawan

7. Menciptakan suasana dan hubungan kerja yang baik

8. Meningkatkan kreativitas dan partisipasi karyawan

9. Meningkatkan tingkat kesejahteraan karyawan

10. Mempertinggi rasa tanggung jawab karyawan terhadap tugastugasnya

\subsection{Jenis-jenis Motivasi}

Ada dua jenis motivasi menurut Malayu Hasibuan (2013: 150) adalah sebagai berikut:

1. Motivasi Positif Motivasi positif maksudnya manajer memotivasi (merangsang) bawahan 
dengan memberikan hadiah kepada mereka yang berprestasi di atas prestasi standar. Dengan motivasi positif, semangat kerja bawahan akan meningkat karena umumnya manusia senang menerima yang baikbaik saja.

2. Motivasi Negatif

Motivasi negatif maksudnya manajer memotivasi bawahan dengan standar mereka akan mendapat hukuman. Dengan motivasi negatif ini semangat bekerja bawahan dalam jangka waktu pendek akan meningkat karena mereka takut dihukum, tetapi untuk jangka waktu panjang dapat berakibat kurang baik.

Dengan demikian dapat dikatakan bahwa motivasi pada dasarnya adalah kondisi mental yang mendorong dilakukannya suatu tindakan (action atau activities) dan memberikan kekuatan yang mengarah kepada pencapaian kebutuhan, memberi kepuasan ataupun mengurangi ketidak seimbangan.

\section{Teori Motivasi}

Maslow (dalam Wukir, 2013:120) Hierarki kebutuhan manusia adalah :

\section{a.Kebutuhan Fisiologis}

Merupakan kebutuhan dasar yang diperlukan manusia untuk bertahan hidup. Kebutuhan ini harus terpenuhi dahulu sebelum seseorang ingin memenuhi kebutuhan diatasnya. Contoh kebutuhan ini adalah makanan, minuman, tempat tinggal dan udara.

\section{b.Kebutuhan Rasa Aman}

Setelah kebutuhan fisiologis terpenuhi maka kebutuhan untuk melindungi diri sendiri menjadi motivasi dari perilaku berikutnya. Kebutuhan ini termasuk stabilitas, kebebasan dari rasa khawatir dan keamanan pekerjaan. Asuransi hidup dan kesehatan merupakan contoh kebutuhan yang masuk ke dalam kategori ini.

c. Kebutuhan Sosial

Setelah kebutuhan tubuh dan keamanan terpenuhi maka muncul kebutuhan baru yaitu rasa memiliki dan dimiliki serta kebutuhan untuk diterima dalam kelompok sosial. Manusia membutuhkan orang lain untuk berhubungan dan berinteraksi. Di tempat kerja kebutuhan ini dapat terpenuhi dengan kemampuan seseorang untuk berinteraksi dengan rekan kerja atau bekerja sama dalam tim.

\section{d.Kebutuhan akan Penghargaan}

Setelah ketiga kebutuhan sebelumnya terpenuhi maka muncul kebutuhan akan penghargaan atau keinginan untuk berprestasi. Kebutuhan ini juga termasuk keinginan untuk mendapatkan repuatasi, wibawa, status, ketenaran, kemuliaan, dominasi, pengakuan, perhatian, kepentingan dan penghargaan.

e.Kebutuhan untuk mengaktualisasikan Diri

Kebutuhan paling akhir yang terletak pada hierarki paling atas muncul setelah semua kebutuhan terpenuhi. Merupakan kebutuhan untuk terus berkembang dan merealisasikan kapasitas dan potensi diri sepenuhnya. 
Dengan demikian dapat dikatakan bahwa motivasi pada dasarnya adalah kondisi mental yang mendorong dilakukannya suatu tindakan (action atau activities) dan memberikan kekuatan yang mengarah kepada pencapaian kebutuhan, memberi kepuasan ataupun mengurangi ketidak seimbangan. Jadi motivasi dalam hal ini, dimana perencanaan pemenuhan keingin pengawas agama Hindu dituntut untuk memilki motivasi diri yang kuat dalam melaksanakan tugas dan fungsi di satuan pendidikan yang dipimpinnya. Hal ini akan mendorong pengawas Agama Hindu tampil sebagai pengawas Agama Hindu yang luar biasa, artinya dimana pengawas agama Hindu mengerjakan tugas pokok dan fungsinya melebihi dari apa yang seharusnya dilakukan menurut standar minimal.Motivasi diri yang ada pada setiap pengawas dalam satuan pendidikan, juga menjadi sumber semangat yang mendorongnya untuk untuk melakukan tindakan terhadap guruguru agama Hindu yang mengajar di Sekolah Dasar.

Motivasi Kerja Pengawas Agama Hindu Sekolah Dasar di Kecamatan Ubud

Pengawas sekolah sebagai tenaga kependidikan mempunyai peran yang sangat strategis dalam meningkatkan kualitas kinerja sekolah melalui pembinaan, pengawasan di bidang akademik dan manajerial. Beratnya tugas seorang pengawas sekolah dalam melaksanakan tugas pokok, fungsi dan tanggung jawab serta wewenangnya itu hanya dapat dipikul oleh seorang pengawas yang memiliki kompetensi yang baik. Berikut akan dipaparkan beberapa hasil wawancara tentang persepsi guru Agama Hindu terhadap pengawas Agama Hindu Sekolah Dasar di Kecamatan Ubud.

Kerti (wawancara hari sabtu, tanggal 21 April 2018) mengatakan bahwa pengawas agama Hindu sangat memperhatikan guru agama Hindu terkait dengan kinerja guru Agama Hindu seperti membimbing guru dalam membuat rencana pelaksanaan pembelajaran (RPP), dan memberikan kebebasan guru untuk memilih model pembelajaran sesuai dengan materi/bahan ajar sehingga guru merasa nyaman dalam melaksanakan tugasnya. Selain itu pengawas Agama Hindu juga menjalin kerjasama seperti membuat group WhatsApp (WA) sehingga informasi sangat cepat sampai begitupula kalau ada permasalahan lebih cepat dapat diselesaikan. Berikutnya juga pengawas Agama menghargai perasaan guru seperti misalnya saat pengawas mau memberikan masukan kepada guru selalu berhati-hati sehingga tidak ada yang merasa tersinggung. Pengawas juga memberikan kesempatan kepada guru-guru Agama Hindu untuk mengembangkan potensinya untuk meningkatkan kualitas pembelajaran.

Selanjutnya, Dadi yang menjabat sebagai ketua Kelompok Kerja Guru Agama Kecamatan Ubud (wawancara hari Sabtu tanggal 21 April 2018) mengatakan bahwa pengawas Agama Hindu memberikan motivasi atau dorongan kepada guru Agama Hindu seperti memberikan bimbingan atau pembinaan dalam penyususan rencana pelaksanaan pembelajaran (RPP), menyusun program semester dan program tahunan sehingga guruguru Agama Hindu merasa nyaman dalam melaksanakan tugas-tugasnya 
sebagai guru. Pengawas Agama Hindu juga dalam melaksanakan tugas-tugasnya sebagai pengawas sesuai dengan ketentuan kepengawasan, namun jika ditemukan hal-hal yang kurang relevan akan diselesaikan dengan kekeluargaan. Pengawas juga sangat menghargai tentang guru-guru Agama Hindu dengan selalu memberikan semangat dalam melaksanakan tugasnya di sekolah. Kegiatan pertemuan Kelompok Kerja Guru (KKG) dilaksanakan secara rutin setiap bulan, mengenai tempat dan waktu biasanya menyesuaikan dengan situasi dan kondisi. Pengawas juga memberikan kesempatan kepada guru-guru Agama Hindu untuk mengikuti pelatihan-pelatihan untuk pengembangan karier guru. Dadi juga mengatakan bahwa pengawas Agama Hindu Sekolah Dasar yang bertugas saat ini sangat mampu memberikan motivasi kepada guruguru Agama SD di Kecamatan Ubud, sehingga guru-guru Agama Hindu mempertahankan agar tetap ditugaskan di Kecamatan Ubud.

Berikutnya, Sri Erawati (wawancara hari sabtu tanggal 28 April 2018) mengatakan bahwa pengawas Agama Hindu memberikan bimbingan secara proaktif dan mengarahkan persiapan proses belajar mengajar seperti memperhatikan kurikulum, RPP, program semester dan tahunan, silabus dan sejenisnya sehingga guru-guru Agama merasa nyaman dalam melaksanakan tugasnya. Selain itu, pengawas Agama Hindu juga sangat mengayomi seperti kalau ada upacara piodalan di sekolah ikut sembahyang bersama. Selain itu, kalau ada guru yang sakit ikut menengok sehingga rasa persaudaraan terjalin dengan baik. Pengawas juga memberikan apresiasi terhadap guru apabila ada siswa yang mendapatkan juara dalam perlombaan seperti Porseni yang rutin diadakan setiap tahun. Pengawas juga memberikan sengat dalam mengembangkan bakat dan kemampuan yang dimilikinya seperti dharmagita atau mengikuti pelatihanpelatihan yang berkaitan dengan tugas sebagai guru.

Dari beberapa uraian hasil wawancara di atas dapat dikatakan bahwa pengawas Agama Hindu Sekolah Dasar di Kecamatan Ubud sangat memperhatikan guru-guru Agama Hindu seperti dalam membimbing penyusunan RPP, silabus, program semester dan sejenisnya sehingga guru merasa nyaman dalam melaksanakan tugasnya. Berikutnya pengawas juga sangat memperhatikan hubungan sosial dan kekeluargaan seperti mebuat group WhatsApp (WA) sehingga informasi dengan cepat diketahui. Pengawas juga menghargai atau menghormati kinerja guru terkait dengan kualitas akademik dan non akademik. Selanjutnya pengawas juga memberikan kebebasan guru untuk mengembangkan potensi atau kemampuan diri sebagai guru.

\section{SIMPULAN}

Berdasarkan uraian di atas dapat disimpulkan bahwa persepsi guru Agama Hindu terhadap motivasi kerja pengawas Agama Hindu di Kecamatan Ubud sangat baik, karena mampu memberikan rasa nyaman dalam melaksanakan tugas-tugas dalam mengelola pembelajaran, mampu membina rasa social, persahabatan, rasa kekeluargaan terhadap guru-guru 
Agama Hindu, menghargai dan menghormati kerja keras guru dalam melaksanakan tugas-tugasnya, dan memberikan dorongan kepada guruguru dalam mengembangkan setip potensi atau kempuan terhadap perkembangan karier guru.

\section{DAFTAR PUSTAKA}

Amri Sopan. 2013.Peningkatan Mutu Pendidikan Sekoluh Dasar dan Menengah. Jakarta: PT Prestasi Pustakaraya

Arikunto, Suharsimi. 2010. Prosedur Penelitian Kualitatf dan Satu Pendekatan

Praktik.Yogyakarta: Rinaka Cipta

Atonius Sukoco. 2007. Arti Definisi/Pengertian Budaya Kerja dan Tujuan Manfaat Penerapan pada Lingkungan Sekitar. Jakarta:Gramedia.

Bernardin. 1993. KinerjaOrganisasi. Jakarta: PT Bumi Aksara

Barata. 2004. Pelayanan Prima Pelanggan. Surabaya: Paramita.

Cudamani.1990. Pengantar Agama Hindu Untuk Perguruan Tinggi.Jakarta:

Yayasan Dharma Sarathi.

Damsar. 2015. Pengantar Teori Sosiologi. Jakarta: PT Aditya Andrebina Agung.

Dwiyanto, A. 2002.Reformasi Birokrasi Publik di Indonesia. Edisi Pertama. Pusat Studi Kependudukan dan Kebijakan. Yogyakarta: UGM.

Darodjat Achmad. 2015. Pentingnya Budaya Kerja tinggi dan kuat.Bandung: PT Refika Aditama.

Effendi dan Widodo. 1999. Pembinaan Pendidikan
http://ejournal.ihdn.ac.id/index.php/AW

Keimanan. Surahaya: Paramita.

Efendi.Sofyan.2010. Membangun BudayaBirokrasi untuk Good Governance.http: sofyan.staff.ugm.ac.id. diakses 23 Maret 2016

Faisal, S. 1996. Pengumpulan dan Analisis Data dalam Penelitian Kualitatif.Malang: FPBS IKIP Malang.

Haherman.AM \& Niiles.NIB.1984. Qualitative Data Analysis. BeverlyHills:

SAGE Publications, Inc

Hiasihuan. Malayu SP. 2005. Organisasi dan Motivasi.Jakarta: Bumi Aksara.

Kanjaya,Dewa Putra. 2002. "Transformasi Pendidikan Agama Hindu (Metode PembelajaranBerbasis NilaiNilai Kemanusiaan“. RadityaNo.57. Hal. 37-44

Keputusan Menteri Agama Republik Indonesia Nomor 381.Tahun 1999 tentang Pengawas sekolah dan pengawas agama adalah pegawaiNegeri Sipil yang diberikan tugas dan tanggung jawab oleh pejabat yang berwenang.

Lang J, 1987, Creating Architectural Theory, The Role of The Behavioral Sciences in Environmental Design, Van Nostrand Reinhold Company Inc, New York.

Machwe, Prabhakar. 2000. Kontibusi Hindu terhadap Ilmu Pengetahuan dan Peradaban. Penerjemah: Ida Bagus Putu Suamba. Editor: Ida Bagus Gde Yudha Triguna. Denpasar: Widya Dharma.

Mantja, W. 2005.Etnografi Desain Penelitian Kualitatif dan 
manajemen Pendidikan.

Malang: Wineka Media

Muhadjar, N. 1996.Metodologi Penelitian Kualitatif. Yogyakarta: Rake Sarani

Murdiasa, I Made.2005.Asta Brata sebagai Salah Satu Pedoman Kepemimpinan dalam Ajaran Agama Hindu.Pontianak Post

Moleong, L.J. 1989. Metodologi Penelitian Kualitatif. Bandung: CV Remaja Karya

Nasir. 1991. Teori-Teori Sosial dan Budaya. Jakarta: Hanoman Sakti

Netra, Anak Agung Gde Oka. 1995. Tuntutan Dasar Agama Hindu. Jakarta: Hanoman Sakti.

Peraturan Pemerintah RI No. 55. Tahun $2007 \quad$ Tentang Pendidikan Agama dan Pendidikan Keagamaan. Direktorat Jenderal Islam Departemen Agama RI.

Sutrisno, Nanang. 2015. Transformasi Kultural dalam Keberagaman Umat Hindu di Kabupaten Banyuwangi. Denpasar: UNHI

Sutrisno, edy. 2010. Budaya Organisasi. Jakarta: Kencana

Titib, I Made. 2003. "Antisipasi Umat Hindu Terhadap Undang-Undang Sistem
Pendidikan Nasional". Raditya Hal. 19-22.

Tika, I Nyoman. 2001. "Metode Alternatif Pendidikan Hindu". Raditya No. 53. Hal.34-46.

Tika Pabunda. 2012. Budaya Organisasi dan Peningkatan Kinerja Perusahaan. Jakarta: PT Bumi Aksara

Undang-Undang Nomor 20, Tahun 2003 tentang Sistem Pendidikan Nasional, Jakarta: Ekajaya. Budi

Wahyu Mahardian. 2007. Membangun aya Kerja. Jakarta: Kencana

Walgito, Bimo. 2004. Pengantar Psikologi Umum. Yogyakarta: Andi.

Webster, Merriam, 1997. New Word Dictionary \& Thesaurus. IDG Books of India Pvt Ltd, New Delhi.

Wibowo. 2011. Budaya Organisasi. Jakarta: PT Raja Gravindo Persada.

Wirawan. 2007. Budaya dan Iklim Organisasi. Jakarta: Salemba Empat.

Pidarta, Made. 1992. Pemikiran

Tentang Supervisi Pendidikan,

Jakarta: Bumi Aksara, ed. 2, cet. I,

h 2

Zakiah Daradjah,1989

. Kesehatan Mental, Jakarta: 